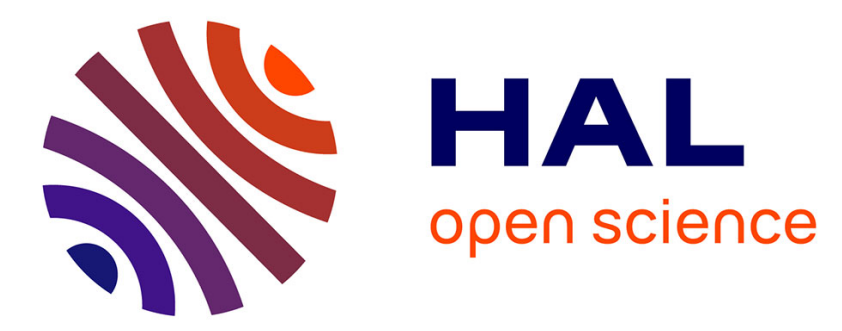

\title{
Gender, socioeconomic status, migration origin and neighbourhood of residence are barriers to HIV testing in the Paris metropolitan area.
}

\author{
Veronique Massari, Annabelle Lapostolle, Emmanuelle Cadot, Isabelle \\ Parizot, Rosemary Dray-Spira, Pierre Chauvin
}

\section{To cite this version:}

Veronique Massari, Annabelle Lapostolle, Emmanuelle Cadot, Isabelle Parizot, Rosemary Dray-Spira, et al.. Gender, socioeconomic status, migration origin and neighbourhood of residence are barriers to HIV testing in the Paris metropolitan area.. AIDS Care, 2011, pp.1. 10.1080/09540121.2011.579940 . hal-00712743

\section{HAL Id: hal-00712743 \\ https://hal.science/hal-00712743}

Submitted on 28 Jun 2012

HAL is a multi-disciplinary open access archive for the deposit and dissemination of scientific research documents, whether they are published or not. The documents may come from teaching and research institutions in France or abroad, or from public or private research centers.
L'archive ouverte pluridisciplinaire HAL, est destinée au dépôt et à la diffusion de documents scientifiques de niveau recherche, publiés ou non, émanant des établissements d'enseignement et de recherche français ou étrangers, des laboratoires publics ou privés. 

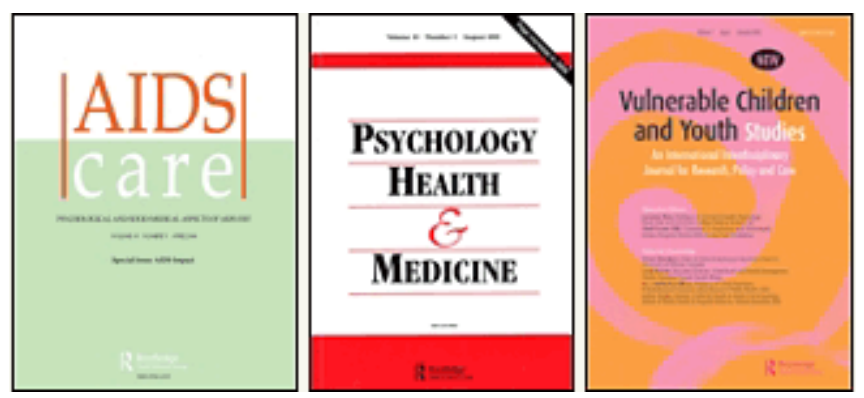

\section{Gender, socioeconomic status, migration origin and} neighbourhood of residence are barriers to HIV testing in the Paris metropolitan area.

\begin{tabular}{|r|l|}
\hline Journal: & $\begin{array}{l}\text { AIDS Care - Psychology, Health \& Medicine - Vulnerable Children } \\
\text { and Youth Studies }\end{array}$ \\
\hline Manuscript ID: & AC-2010-07-0416.R2 \\
\hline Journal Selection: & AIDS Care \\
\hline Keywords: & $\begin{array}{l}\text { HIV testing, gender, social inequalities, migration status, } \\
\text { neighbourhood status }\end{array}$ \\
\hline
\end{tabular}

\section{SCHOLARONE Manuscripts}




\section{Abstract}

In France, numerous HIV patients still discover their HIV status as a result of AIDS-related symptoms. We investigated factors related to the absence of any HIV testing in men and women separately, using the data from the SIRS cohort, which includes 3023 households representative of the Paris metropolitan area in 2005. The failure to use HIV testing services was studied in relation to individual socioeconomic and demographic factors as well as some psychosocial characteristics. The effect of the characteristics of the residential neighbourhood was also analysed using multilevel models. In multivariate analysis, the factors associated with no history of HIV testing in women were an age $>44$, the absence of any pregnancy during the previous 15 years, a low education level, unemployment, to have had no or only one steady relationship in one's lifetime, to have a religious affiliation and to live in a poor neighbourhood. In men, factors were age $<30$ or $>44$, to have had no or only one steady relationship during one's lifetime, to have a religious affiliation and to perceive oneself as being at low risk of HIV infection. An association according to the 'migration origin' was observed among men: foreigners and French men born to (at least) one foreign parent were more likely not to have been tested than French men born to two French parents. We conclude that gender, social and territorial differences exist in HIV testing among people living in the Paris area. More systematic proposals of HIV test in primary care would be an effective policy to overcome these persistent social stratifications.

\section{Introduction}

Despite having one of the highest level of HIV testing rate in Europe, (Van Casteren et al., 1993), French national statistics indicate that numerous HIV- 
positive patients present for treatment with a CD4 count $<200$ cells $/ \mu \mathrm{L}$ and $52 \%$ of AIDS cases are unaware of their HIV infection at the time of diagnosis (InVS, 2007) when a late diagnosis is known to be associated with an increased risk of mortality after entry into the health-care system (Sterne et al., 2009). In France, HIV testing policy is based on the opt-in approach. Since 1993, HIV testing is offered systematically by health professionals to pregnant women. HIV testing is widely delivered in hospitals, in free and anonymous testing settings, and also largely provided in primary care. Data from a French national HIV testing surveillance system, based on a representative sample of general practitioners showed that only $11 \%$ of the tests ordered annually were performed in individuals belonging to high-risk groups or after high-risk behaviours (Massari, Dorléans, \& Flahault, 2005).

Among AIDS cases, a late HIV diagnosis is significantly more frequent in immigrants than in French-born individuals (64\% vs. 41\%) which suggests that access to HIV diagnosis and antiretroviral treatments was unequal, even though both are available free of charge in France (InVS, 2007).

In France, like in most industrialized countries, numerous studies have identified a link between individuals' socioeconomic situation (SES) and their health status and/or their use of health services. More recent studies have focused on the neighbourhood factors associated with health (Silhol, Zins, Chauvin, \& Chaix, 2011) or health care (Vallée, Cadot, Grillo, Parizot, \& Chauvin, 2010), after adjustment for individuals' SES.

Some studies have reported that disparities in health outcomes exist between immigrants and native-born individuals (Jusot, Silva, Dourgnon, \& Sermet, 2009), but as such they remain rare. Indeed, unlike in countries such as the United States or Great Britain, it is not legal in France to routinely categorize people into racial, 
ethnic or religious groups, and capturing the citizenship and/or country of birth of individuals and those of their parents is rarely done and is governed by strict legal rules. For these reasons, French studies on the social and migrational determinants of HIV testing are scarce (Le Vu \& Lydié, 2005) although some studies devoted to French women from overseas territories (Halfen, 2008) or African women (Lydié, 2008) were published. More generally, studies that address barriers to and facilitators of HIV testing in high-income countries are scarce (De Wit \& Adam, 2008; Deblonde et al., 2010), particularly those highlighting the situation of their minorities (Wohl, Tejero, \& Frye, 2009) and their migrant populations (Stolte, et al., 2003; Fakoya, Reynolds, Caswell, \& Shiripinda, 2008).

The purpose of this study was to determine predictors of the failure to use HIV testing among men and women separately in a representative sample of residents of the Paris metropolitan area, including socioeconomic factors, certain psychosocial characteristics, and two other main dimensions: their 'migration origin' and the socioeconomic status of their neighbourhood of residence.

\section{Methods}

\section{Participants and procedure}

The SIRS (French acronym for health, inequalities and social ruptures) cohort is the first large, representative, population based French cohort set up to study the social determinants of health and health care utilization. In this cohort, the respondents' addresses are geocoded, and a large number of social and health-related characteristics were captured during at-home, face-to-face interviews.

Our study population was a multistage sample randomly selected from the general population living in the Paris metropolitan area. The primary sampling units were census blocks: 50 of them were randomly selected from the 2595 eligible census blocks in Paris and its suburbs, and the poorest ones were 
overrepresented. At the second level, 60 households were randomly selected in each census block. Finally, we randomly selected one French-speaking adult per household by the birthday method (the adult chosen was the person in the household with the next birthday). Data were collected between September and December 2005. Further details on the sample methodology have been published elsewhere (Roustit et al., 2009). Of the 4560 adults initially contacted to participate, $29 \%$ declined to answer, $3 \%$ did not speak French, and $2 \%$ could not answer for health reasons.

\section{Measures}

Outcome- The outcome variables were having had an HIV test and the circumstances for having been tested, both over the individual's lifetime. Four closed (yes/no) questions were asked about having been tested at least once for HIV: 1) at any time during one's lifetime; 2) at one's own request; 3) as part of a systematic or routine examination (pregnancy, marriage, blood donation); and 4) on a physician's recommendation. The interviewees were asked about the date of their last HIV test.

Demographics- A first set of independent variables examined in this study were demographic characteristics, including age, gender, marital status, and 'migration origin'. The latter was defined and categorized by distinguishing between French born to two French parents, French born to at least one foreign parent, and foreigners. Because HIV screening for all pregnant women had been widely offered since 1990 (Massari et al., 2005), having a child <15 (or being pregnant at the time of the survey) was included.

Socioeconomic status- Several characteristics related to the individuals SES were taken into account: education level (primary or less, lower secondary, upper secondary and university), employment status (employed, unemployed and inactive 
-including retired or student), occupational category (coded as inactive, lower white-collar, tradespeople-salespeople, upper white-collar, blue-collar and intermediate occupations), monthly income per household unit (HU), which was divided into quartiles, and health care utilization status, including health insurance status, having a regular general practitioner (or not), and having forgone health care for financial reasons during the previous 12 months (or not).

Psychosocial characteristics- The individual's self-perception of HIV risk (ranked as low or high) was taken into account, as well as certain characteristics pertaining to some of their social ties and social support: the self-perceived feeling of being supported by friends, relatives or neighbours (or not), the fact of living alone (or not), and the number of steady couple relationships over the individual's lifetime. Finally, the interviewees were asked about their religious affiliation, if any (but not about their religion itself).

Neighbourhood characteristics- At the neighbourhood level, we used the mean monthly household income in the neighbourhood as an indicator of its socioeconomic type (SET). It was calculated using the 2005 income tax database (provided by French tax authorities) and divided into quartiles.

\section{Statistical analyses}

We used $\chi^{2}$ tests to identify potential differences among participants who reported having been tested for HIV and those who did not. First, all the selected variables associated with our dependant variable with a $p$-value $<0.20$ were introduced in two multivariable regression models (for men and women separately) and were then backward-selected. Decisions concerning potential covariates retained in the final models were based on the Hosmer approach using a threshold $p<0.05$. All of these statistical analyses were weighted to take into account the sampling method -and 
the poststratification adjustment for age and gender according to the general population census data. The survey logistic procedure $\left(\mathrm{SAS}^{\circledR} \mathrm{v} .9 .1\right)$ was used to estimate the parameters, confidence intervals and statistical tests. Second, we computed multilevel models using Stata ${ }^{\circledR} \mathrm{v} .10$ with the xtmelogit procedure (specifying that collected data were clustered by census block). The multilevel modelling strategy was carried out in three steps. First, a null model was computed to estimate the area-level variations. Second, individual independent variables selected by the previous logistic regression procedure were included to test for the compositional effect. Finally, the neighbourhood-level characteristic was introduced into the model. To test for area-level variation, the level-2 variance and the median odds ratio (MOR) were estimated at each step. The MOR measures the median value of the adjusted OR between the most and least at-risk individual when comparing all pairs of neighbourhoods (Larsen \& Merlo, 2005).

\section{Results}

The participation rate in the survey was $71 \%$. The sample consisted of 1423 men (47.1\%) and 1600 women (52.9\%). With regard to SES (Table 1), 56.4\% were active, $83.6 \%$ had complete health insurance, $18.4 \%$ of the subjects were living alone and $5.5 \%$ were socially isolated. The participants' mean age at the time of interview was 44.1 years for men and 45.7 years for women.

In our sample, $55.4 \%$ of people had been tested for HIV at least once during their lifetime: $46.7 \%$ had been tested at least once at their request, $61.7 \%$ during a systematic or routine examination, and $13.6 \%$ at their physician's request. Subjects who answered that they did not know whether or not they had been tested $(n=33)$ were grouped with the never-tested subjects. Of the tested subjects, $20.4 \%$ had been tested during the previous twelve months, $47.6 \%$ during the previous $1-4$ years, $18.8 \%$ during the previous $6-10$ years and $13.1 \%>10$ years earlier. The proportion 
of tested subjects varied widely according to the neighbourhood: $17.6 \%$ to $82.6 \%$ in men, and $28.6 \%$ to $83.7 \%$ in women. Men were more likely to have never been tested for HIV than women ( $48 \%$ vs. $41 \%, p<0.001)$.

In men, the factors positively associated with no history of HIV testing in univariate analysis were young $(<25$ years) or old age ( $>60$ years), lower education level, lower income, being a foreigner or being a French born to at least one foreign parent, not having any children $<15$, not living in a couple relationship, having had no or only one steady relationship, having a religious affiliation, having a regular general practitioner, perceiving oneself to be at low risk for HIV infection, being unemployed or a blue-collar worker, not living alone, and living in a poor neighbourhood (Table 1). Health insurance status, social support and having foregone health care were not associated with our outcome.

In women, the factors positively associated with no history of HIV testing were age $>60$ years, lower education level, not living in a steady relationship, not having any children $<15$, not being employed or a blue-collar worker, living alone, never having had steady relationship, and having a religious affiliation. Migration origin, income, health insurance status, social support, having a regular general practitioner, self-perception of HIV risk, and the neighbourhood mean income were not associated with our outcome.

Table 2 presents the results of the multilevel regression models for women. The empty model shows an area-level effect in terms of no history of HIV testing (area-level variance of 0.101 [0.045]). The second model, which includes the individual variables, shows that, in women, factors associated with never having been tested for HIV included age-groups $\geq 45$ years; no children $<15$ (aOR=2.82); low education level $\quad\left(\mathrm{aOR}_{\leq \text {primary vs. university }}=2.51 \quad\right.$ and $\mathrm{aOR}_{\text {lower- }}$ secondary vs. university $=1.70)$; being unemployed $\left(\mathrm{aOR}_{\text {unemployed vs. employee }}=1.85\right)$; and 
having had no steady relationship $\left(\mathrm{aOR}_{\text {none vs. } \geq 3 \text {-relationships }}=4.32\right)$ or only one $\left(\mathrm{aOR}_{\text {one vs. } \geq 3 \text {-relationships }}=2.55\right)$. The inclusion of these individual variables accounted for $41.58 \%$ of the area-level variance.

After the introduction of neighbourhood-level variables, the effect of all the individual variables remained statistically significant and stable. In women, the neighbourhood mean income was associated with never having been tested for HIV $\left(\mathrm{aOR}_{3 \mathrm{rd}-\text { quartile vs. } 1 \text { st-quartile}}=0.63\right)$. The area-level variance $(0.028[0.037])$ was no more significantly different from zero when both the individual and area variables were taken into account.

In men (Table 3), an area-level effect was found in the null model (level-2 variance of 0.103 [0.059]). After the introduction of the individual variables in the second model, the level-2 variance was no more significantly different from zero. In this model, factors associated with never having been tested for HIV included age-groups other than 30-44 years, low education level $\left(\mathrm{aOR}_{\text {primary vs. university }}=1.85\right)$; the number of steady relationships during one's lifetime (none or only one) and the perceived risk of $\mathrm{HIV}$ infection $\left(\mathrm{aOR}_{\text {low vs. high }}=1.69\right)$. Moreover, in men, a religious affiliation was significantly associated with no history of HIV testing (aOR=1.35). An association with migration origin was also observed: compared to French men born to two French parents, foreigners $(\mathrm{aOR}=1.62)$ and French men born to at least one foreign parent $(\mathrm{aOR}=1.64)$ were more likely to have never been tested. All these individual factors remained statistically significant in the last model, which also includes the neighbourhood mean income (which was not significantly associated with our outcome).

\section{Discussion}

Our data show that in 2005, in the Paris area, men were less likely to have been 
tested at least once during their lifetime than women. In both sexes, not having been tested for HIV was significantly associated with an older age, a low education level, the absence or only one steady relationship during one's lifetime, and a religious affiliation. Furthermore, in men, never having been tested for HIV was associated with a low self-perceived risk for HIV infection, and the migration origin. In women, other associated factors were being inactive and having no children $<15$.

Our study also shows differences between neighbourhoods in the likelihood of women never having been tested, which persisted after taking individual characteristics into account and which is, at least partially, explained by a contextual variable, such as neighbourhood mean income. On the contrary, in men, the significant differences in the observed crude prevalence rates of HIV testing between neighbourhoods are fully explained by a composition effect.

The individuals were interviewed retrospectively about any previous HIV testing. The last test had been performed an average of about five years before the survey date. Thus, a recall bias concerning the circumstances of the last test is possible. In addition, some respondents, especially foreigners and the less educated, may have confused certain routine laboratory tests and the HIV screening test, which would have led to an overestimation of HIV testing.

Because no data had been collected on the respondents' sexual behaviours, or practices related to the prevention of HIV transmission, we could not explore the contribution of these factors to the differences observed. Similarly, reasons for never having been tested were not investigated upon the individuals' inclusion in this multipurpose health and social cohort. Finally, the respondents' HIV status was not taken into account here because the number $(n=27)$ of infected people in our sample was low (approximately 1\% of the total, which is the number expected 
according to the HIV prevalence in Paris area).

Many studies on the utilization of health-care services have shown that people with a low SES are less likely to avail themselves of preventive care, even in countries where national health services and/or universal and public health insurance should preclude any financial obstacles to access to such care.

In pregnant women or women with children $<15$, the proportion of subjects who had been tested was as high as $84.8 \%$. Pregnancy is the most common reason for HIV diagnosis in sub-Saharan African women, whereas it is the second after clinical symptoms among French-born women. Universal voluntary HIV testing of pregnant women is the key to prevention of mother-to-child transmission (MTCT) of HIV. Data from the French Perinatal Cohort showed that the proportion of women without ART during the pregnancy rapidly decreased from $15.6 \%$ in 19941996 to around $3.0 \%$ in the period 1997-2004. African and French women did not differ in terms of access to HAART, nor for substandard management (Jasseron, et al, 2008).

We found also that people who had had zero or only one steady relationship in their lifetime were less likely to have been tested. Starting a steady relationship is still one of the most frequent reasons for getting tested for HIV: in 2004, 39\% of the people had undergone HIV testing to stop using condoms with their partner or as part of their pre-nuptial examination (ORS 2005). Another French-study found that being in a steady relationship and having children make people feel that they are less at risk for HIV and cause them to be at greater risk for late diagnosis (Delpierre et al., 2006). Generally speaking, since they are not priority targets for testing, current French policy results in people at low risk for HIV infection being at high risk for late detection (Delpierre, Cuzin, \& Lert, 2007).

We found that subjects of both sexes with a religious affiliation were less likely http://mc.manuscriptcentral.com/ac-phm-vcy 
to have been tested than those without any. Monotheistic religions hold multiple discourses but generally highlight the concepts of abstinence and fidelity within marriage as a model for risk prevention against HIV infection (Santelli, 2008). In communities where religion plays an important role, people may attach more importance to messages from religious leaders than to those concerning prevention based on sexual behaviours (Maulana, Krumeich, \& Van Den Borne, 2009)

We previously reported certain geographical variations in health care utilization in France (Vallée et al., 2010), but such studies have never been conducted on HIV testing. In the literature, a recent study on neighbourhood effects on HIV testing in Los Angeles County found significant geographical disparities (Taylor, Leibowitz, Simon, \& Grusky, 2006). Another study, albeit ecological, showed that people living in the most materially deprived areas were less likely to have been tested for HIV during their lifetime (Singh Setia, Quesnel-Vallee, Curtis, \& Lynch, 2009).

Our study shows that the area-level effect for women observed in the null model is fully explained after the introduction of both individual and area variables. In men, the geographical variation in HIV testing across neighbourhoods observed in the null model is no more significant after individual variables are introduced. So, the wide between-neighbourhood variability observed in the testing rates in our study can mostly be explained by a compositional effect more than by a contextual effect, and this particularly for men. Of course, this distinction between compositional effect (related to the residents' individual characteristics) and contextual effect (related to the characteristics of their neighbourhood of residence) may appear artificial and of a somewhat simplifying nature. Indeed, for some authors, the two effects are inextricably bound together: "People make places and places make people" (Cummins, Curtis, Diez-Roux, \& Macintyre, 2007). This 
distinction is used here as a reductionist framework suitable for performing proper statistical analyses.

Studies conducted in other countries report that foreign-born people are less likely to seek medical assistance or preventive care, such as cancer screening, than native-born citizens (Brown, Consedine, \& Magai, 2006). We found a significant difference in HIV testing rates according to people's migration origin. Following the French health policies instituted in 2003 , it was already known that male immigrants from countries where the HIV/AIDS prevalence was high were more likely to get tested than French born individuals (Le Vu \& Lydié, 2008). In our survey, $78.5 \%$ of sub-Saharan African people had been tested versus $39.7 \%$ of North African and $46.6 \%$ of people from other countries $(\mathrm{p}<0.0001)$. The comparatively low HIV testing rate among North African immigrants may be linked to the traditional and religious environment in their countries of origin, where strong taboos with consequent stigma are associated with AIDS and create barriers to accessing HIV prevention, testing and treatment (Remien et al., 2009).

As regards French natives born to at least one foreign parent, our analysis is the first in France to have been obtained from a representative, population-based health survey, since they are largely invisible in routine statistics and most surveys, including in the field of HIV/AIDS. However, it would seem important to study and take account of this population group in France, the European country with the longest and most important history of immigration since the beginning of the $20^{\text {th }}$ century. First, because of this history, $11 \%$ of the French population was born to at least one immigrant, and we estimated that they account for $17.7 \%$ of the population of the Paris metropolitan area. Second, being younger than the French general population, they are proportionally more often in the active sexual period of their lives and are (or should be) particularly concerned about sexual health and 
care, including HIV/AIDS issues. Third, recent social surveys indicate that their SES is, overall, worse than that of French people born to French parents, even if a majority of them was born and raised in France. They are children of parents of various origins and cultures (mainly Southern Europe and French-speaking countries of North and sub-Saharan Africa) and their social status is somewhere between the second- or higher-generation French and immigrants. For the first time in France, our results show that some of the men in this group are also underprivileged in terms of HIV testing. This is observed in a model adjusted for education level, religious affiliation, the perceived risk of HIV infection, and the number of steady relationships. A possible explanation would be that they are more concerned about privacy and the fear for discrimination if the result of the test would not be kept secret - a justification cited as a main reason for no testing by $15.4 \%$ of the population of Paris area, in a regional KAPB study (ORS, 2005).

\section{Conclusion}

Our results suggest that HIV screening policies should take into account the observed social stratification to ensure that everyone can suitably access and use HIV screening services, including immigrants and French people born to immigrant parents, of whom there are many in France, particularly in the Paris metropolitan area, the most populated, wealthiest (but also socially diversified) and AIDSstricken region in France.

To promote more systematic HIV test proposals by the caregivers in primary care (Yazdanpanah, Lange, Gerstoft \& Cairns, 2010) should be an effective policy to overcome these persistent social stratifications. First, a French simulation study has showed that one-time, universal, routine HIV counselling, testing and referral would meet the standards of cost-effectiveness (Yazdanpanah et al., 2010). Second, since the French health system already provides universal free HIV testing, 
regardless of social status, differences may exist because of obstacles other than financial ones (Delpierre et al., 2006). In particular, knowledge and attitudes regarding infection and prevention, including HIV testing, should play a role in the observed differences. As we know, fear and the anticipation of the social consequences of the disease can be a deterrent to HIV testing or to returning for the result (Obermeyer \& Osborn, 2007). Such attitudes should be changed by disseminating proper information to those the more in need (the underprivileged, the immigrants and the French people born to immigrants) when proposing more routinely HIV tests in primary care.

Our results corroborate the new strategy for the prevention and control of HIV for the years 2010-2014 recently adopted in France. It recommends the universal screening of the general population with the specific targets to the most vulnerable populations including those who may stay away from the existing screening services.

\section{References}

Brown, W. M., Consedine, N. S., \& Magai, C. (2006). Time spent in the United States and breast cancer screening behaviors among ethnically diverse immigrant women: evidence for acculturation? Journal of Immigrant and Minority Health, 8, 347-358. doi: 10.1007/s10903-006-9005-y.

Cazein, F., Le Vu, S., Pilonnel, J., Le Strat, Y., Couturier, S., Basselier, B., Lot, F. \& Semaille C. (2010). HIV testing activity in France, 2003-2009. Bulletin Epidémiologique Hebdomadaire, (45-45), 451-454 (in French).

Cummins, S., Curtis, S., Diez-Roux, A. V., \& Macintyre, S. (2007). “Understanding and representing 'place' in health research: A relational approach." Social Science \& Medicine, 65(9), 1825-1838. doi:10.1016/j.socscimed.2007.05.036.

Cunningham, S. A., Ruben, J. D., \& Narayan, K. M. V. (2008). Health of foreignborn people in the United States: A review. Health \& Place, 14, 623-625. 
Delpierre, C., Cuzin, L., Lauwers-Cances, V., Marchou, B., \& Lang, T. (2006). High-risk groups for late diagnosis of HIV infection: A need for rethinking test policy in the general population. AIDS Patient Care \& STDs, 20, 838-846. doi: 10.1089/apc.2006.20.838.

Delpierre, C., Cuzin, L., \& Lert, F. (2007). Routine testing to reduce late HIV diagnosis in France. British Medical Journal, 334(5), 1354-1356. doi: 10.1136/bmj.39225.458218.94.

Deblonde, J., de Koker, P., Hamers, F. F., Fontaine, J., Luchters, S., \& Temmerman, M. (2010). Barriers to HIV testing in Europe: a systematic review. European Journal of Public Health, 20(4), 422-432. doi: 10.1093/eurpub/ckp231.

De Wit, J. B., \& Adam, P. C. (2008). To or not to test: psychosocial barriers to HIV testing in high-income countries. HIV Medicine, 9 suppl 2, 20-22. doi: 10.1111/j.1468-1293.2008.00586.x.

Fakoya, I., Reynolds, R., Caswell, G., Shiripinda, I. (2008). Barriers to HIV testing for migrant black Africans in Western Europe. HIV Medicine, 9 suppl 2:2325. doi: 10.1111/j.1468-1293.2008.00587.x.

Halfen, S. (2008). Sexual and preventive behavior in the French Antilles and Guyana: an unfavorable context for the women facing HIV/AIDS. In: "Women and HIV in France". Médecine Sciences, 24(HS2), 72-80 (in French).

Institut de Veille Sanitaire (2007). Strike against HIV/AIDS and sexually transmitted diseases in France. 10 years of surveillance, 1996-2005. Saint Maurice (in French).

Jasseron, C., Mandelbrot, L., Tubiana, R., Teglas, J.P., Faye, A., Dollfus, C., Le Chenadec, J., Rouzioux, C., Blanche, S., \& Warszawski, J. (2008). ANRS French Perinatal Cohort. Prevention of mother-to-child HIV transmission: similar access for sub-Sahara African immigrants and for French women? AIDS, 22(12), 1503-1511.

Jusot, F., Silva, J., Dourgnon, P., \& Sermet, C. (2009). Health inequalities related to immigration in France. Effects of living conditions or selective migration. Revue économique, 2(60), 385-411 (in French). 
Larsen, K., \& Merlo, J. (2005). Appropriate Assessment of Neighborhood Effects on Individual Health: Integrating Random and Fixed Effects in Multilevel Logistic Regression. American Journal of Epidemiology, 161(1), 81-88. doi: 10.1093/aje/kwi017.

Le Vu, S., \& Lydié, N. (2008). Practices of HIV testing among people from subSaharan Africa in the Ile de France, 2005. Bulletin Epidémiologique Hebdomadaire, 7-8, 52-55 (in French).

Lydié, N. (2008). The African women facing HIV/AIDS: risk perception and managment. In: "Women and HIV in France". Médecine Sciences, 24(HS2), 81-89 (in French).

Massari, V., Dorléans, Y., \& Flahault, A. (2005). Trends in HIV voluntary testing in general practices in France between 1987 and 2002. European Journal of Epidemiology, 20(6), 543-547. doi: 10.1007/s10654-005-4265-8.

Maulana, A. O., Krumeich, A., \& Van Den Borne, B. (2009). Emerging discourse: Islamic teaching in HIV prevention in Kenya. Culture, Health \& Sexuality, 11, 559-569. doi: 10.1080/13691050902792771.

Obermeyer, C. M., \& Osborn, M. (2007). The utilization of testing and counseling for HIV: A review of the social and behavioral evidence. American Journal of Public Health, 97, 1762-1774. doi: 10.2105/AJPH.2006.096263.

ORS Ile-de-France. (2005). Surveillance of HIV/AIDS in Ile-de-France. Bulletin de santé, 10, 1-8 (in French).

Remien, R. H,. Chowdhury, J., Mokhbat, J. E., Soliman, C., El Adawy, M., \& El Sadr, W. (2009). Gender and access to HIV testing, care and treatment. Journal of Acquired Immune Deficiency Syndrome, 51, S106-S110. doi: 10.1097/QAI.0b013e3181aafd66.

Roustit, C., Renahy, E., Guernec, G., Lesieur, S., Parizot, I., \& Chauvin, P. (2009). Exposure to interparental violence in childhood and psychosocial maladjustment in the adult life course: advocacy for early prevention. Journal of Epidemiology \& Community Health, 63, 563-568. doi: 10.1136/jech.2008.077750.

Santelli, J. S. (2008). Medical accuracy in sexuality education: ideology and the scientific process. American Journal of Public Health, 98, 1786-1792. doi: 10.2105/AJPH.2007.119602. 
Silhol, R., Zins, M., Chauvin, P., Chaix, B. (2011). Investigating the spatial variability in incidence of coronary heart disease in the Gazel Cohort: the impact of area socioeconomic position and mediating role of risk factors. Journal of Epidemiology \& Community Health, 65, 137-143. doi: 10.1136/jech.2009.087379.

Singh Setia, M., Quesnel-Vallee, A., Curtis, S., \& Lynch, J. (2009). Assessing the role of individual and neighbourhood characteristics in HIV testing: evidence from a population based survey. Open AIDS Journal, 3, 46-54. doi: $10.2174 / 1874613600903010046$.

Sterne, J. A., May, M., Costagliola, D., de Wolf, F., Phillips, A. N., Harris, R., et al. (2009). Timing of initiation of antiretroviral therapy in AIDS-free HIV-1infected patients: a collaborative analysis of $18 \mathrm{HIV}$ cohort studies. Lancet, 373(9672), 1352-1363. doi: 10.1016/S0140-6736(09)60612-7

Stolte, I.G., Gras, M., Van Benthem, B.H., Coutinho, R.A., van den Hoek, J.A. (2003). HIV testing behaviour among heterosexual migrants in Amsterdam. AIDS Care, 15, 563-574.

Taylor, S. L., Leibowitz, A., Simon, P. A., \& Grusky, O. (2006). ZIP code correlates of HIV-testing: a multi-level analysis in Los Angeles. AIDS Behaviors, 10(5), 579-586. doi: 10.1007/s10461-005-9064-4.

Vallée, J., Cadot, E., Grillo, F., Parizot, I., \& Chauvin, P. (2010). The combined effects of activity space and neighbourhood of residence on participation in preventive health-care activities: The case of cervical screening in the Paris metropolitan area (France). Health Place, 16(5), 838-852. doi: 1 0.1016/j.healthplace.2010.04.009.

Van Casteren, V., Bartelds A., Gurtner, F., Massari, V., Maurice-Tison, S., \& Vega Alonso, T. (1993). Demand patterns for HIV tests in general practices: information collected by sentinel network in five European countries. European Journal of Epidemiology, 9, 169-175.

Wohl, A.R., Tejero, J., Frye, D.M. (2009). Factors associated with late HIV testing for Latinos diagnosed with AIDS in Los Angeles. AIDS Care, 21(9), 12031210. doi: 10.1080/09540120902729957

Yazdanpanah, Y., Sloan, C. E., Charlois-Ou, C., Le Vu, S., Semaille, C., Costagliola, D., Pillonel, J., Poullié, A. I., Scemama, O., Deuffic-Burban, S., 
Losina, E., Walensky, R. P., Freedberg, K. A., Paltiel, A. D. (2010). Routine HIV screening in France: clinical impact and cost-effectiveness. PLoS One, 5(10), e13132.

Yazdanpanah, Y., Lange, J., Gerstoft, J., Cairns, G. (2010). Earlier testing for HIVhow do we prevent late presentation? Antiviral Therapy, 15, Suppl 1, 17-24.

\section{Acknowledgments}

The SIRS cohort study has been supported by the Institute for Public Health Research (IRESP), the Directorate-General of Health (DGS), the Interministerial Delegation for Urban Affairs (DIV), the European Social Fund, the Regional Council of Ile-de- France and the City of Paris. This study was part of a research project supported by a grant from the French National Agency for Research on Aids (ANRS). 
Table 1. Comparison of the characteristics of the HIV-tested and never-tested subjects according to gender (weighted data).

\begin{tabular}{|c|c|c|c|c|c|c|c|c|}
\hline & $\begin{array}{c}\text { Overall } \\
(n=3023)\end{array}$ & $\%$ & $\begin{array}{c}\text { Never- } \\
\text { tested men } \\
(\mathrm{n}=693)\end{array}$ & $\%$ & $\begin{array}{c}P \text {-value } \\
\text { (tested vs. } \\
\text { never-tested) }\end{array}$ & $\begin{array}{l}\text { Never- } \\
\text { tested } \\
\text { women } \\
(\mathrm{n}=657) \\
\end{array}$ & $\%$ & $\begin{array}{c}P \text {-value } \\
\text { (tested vs. } \\
\text { never-tested) }\end{array}$ \\
\hline \multicolumn{9}{|l|}{ Age group } \\
\hline 18-29 years & 707 & 23.39 & $199 / 342$ & 58.04 & $<0.0001$ & $127 / 365$ & 34.76 & $<0.0001$ \\
\hline $30-44$ years & 920 & 30.43 & $131 / 451$ & 29.16 & & $80 / 470$ & 17.13 & \\
\hline 45-59 years & 715 & 23.65 & $164 / 352$ & 46.39 & & $152 / 362$ & 42.00 & \\
\hline$\geq 60$ years & 681 & 22.53 & $199 / 277$ & 71.80 & & $298 / 404$ & 73.71 & \\
\hline \multicolumn{9}{|l|}{ Marital status } \\
\hline $\begin{array}{l}\text { Married or living in a couple } \\
\text { relationship }\end{array}$ & 1910 & 63.18 & $415 / 907$ & 45.80 & & $361 / 1003$ & 36.05 & $<0.0001$ \\
\hline Other & 1113 & 36.82 & $277 / 516$ & 53.74 & 0.0116 & $296 / 598$ & 49.48 & \\
\hline \multicolumn{9}{|l|}{ Migration origin } \\
\hline French/French parents & 2068 & 68.41 & $439 / 1004$ & 43.73 & $<0.0001$ & $448 / 1064$ & 42.14 & 0.2526 \\
\hline French/foreign parent(s) & 536 & 17.73 & $133 / 225$ & 59.09 & & $129 / 311$ & 41.40 & \\
\hline Foreigner & 419 & 13.86 & $120 / 193$ & 62.24 & & $80 / 226$ & 35.51 & \\
\hline \multicolumn{9}{|l|}{ Children } \\
\hline No children under 15 years & 1984 & 65.63 & $517 / 945$ & 54.73 & $<0.0001$ & $574 / 1040$ & 55.21 & $<0.0001$ \\
\hline Children under 15 years* & 1039 & 34.37 & $176 / 478$ & 36.71 & & $83 / 561$ & 14.82 & \\
\hline \multicolumn{9}{|l|}{ Education level } \\
\hline$\leq$ Primary & 294 & 9.73 & $87 / 126$ & 69.49 & $<0.0001$ & $126 / 168$ & 79.84 & $<0.0001$ \\
\hline Lower secondary & 531 & 17.57 & $147 / 252$ & 58.25 & & $134 / 280$ & 47.87 & \\
\hline Upper secondary & 643 & 21.27 & $145 / 303$ & 47.97 & & $129 / 340$ & 37.99 & \\
\hline University & 1555 & 51.44 & $313 / 742$ & 42.19 & & $268 / 812$ & 32.98 & \\
\hline \multicolumn{9}{|l|}{ Employment status } \\
\hline Working & 1704 & 56.37 & $346 / 863$ & 40.05 & $<0.0001$ & $228 / 817$ & 27.92 & $<0.0001$ \\
\hline Unemployed & 285 & 9.43 & $84 / 156$ & 53.72 & & $38 / 129$ & 29.08 & \\
\hline Retired, inactive, student & 665 & 22.00 & $263 / 403$ & 65.19 & & $392 / 654$ & 59.84 & \\
\hline \multicolumn{9}{|l|}{ Socio-occupational categories } \\
\hline Unemployed & 327 & 10.82 & $70 / 115$ & 61.14 & 0.0084 & $110 / 208$ & 52.74 & 0.0070 \\
\hline Blue collar & 377 & 12.47 & $181 / 311$ & 58.07 & & $31 / 66$ & 46.95 & \\
\hline Lower white-collar & 721 & 23.85 & $99 / 184$ & 53.62 & & $232 / 537$ & 43.20 & \\
\hline Tradespeople, salespeople & 141 & 4.66 & $48 / 97$ & 49.97 & & $21 / 45$ & 46.03 & \\
\hline Intermediate occupations & 666 & 22.03 & $112 / 259$ & 43.20 & & $148 / 407$ & 36.34 & \\
\hline Upper white-collar & 791 & 26.17 & $183 / 455$ & 40.16 & & $116 / 336$ & 34.41 & \\
\hline \multicolumn{9}{|l|}{ Health insurance (HI) } \\
\hline $\mathrm{HI}+$ additional insurance & 2528 & 83.63 & $573 / 1188$ & 48.21 & 0.2239 & $545 / 1340$ & 40.69 & 0.4129 \\
\hline HI for the poor & 172 & 5.69 & $33 / 61$ & 54.78 & & $42 / 111$ & 37.73 & \\
\hline $\begin{array}{l}\text { HI without additional } \\
\text { insurance }\end{array}$ & 304 & 10.06 & $80 / 167$ & 47.99 & & $66 / 137$ & 48.06 & \\
\hline None & 19 & 0.63 & $7 / 7$ & 90.59 & & $4 / 12$ & 33.43 & \\
\hline
\end{tabular}

* including 24 pregnant women 
Table 1 (Cont'd). Comparison of the characteristics of the HIV-tested and never-tested subjects according to gender (weighted data).

\begin{tabular}{|c|c|c|c|c|c|c|c|c|}
\hline & $\begin{array}{c}\text { Overall } \\
(n=3023)\end{array}$ & $\%$ & $\begin{array}{c}\text { Never- } \\
\text { tested men } \\
(n=693)\end{array}$ & $\%$ & $\begin{array}{c}P \text {-value } \\
\text { (tested vs. } \\
\text { never- } \\
\text { tested }\end{array}$ & $\begin{array}{c}\text { Never-tested } \\
\text { women } \\
(n=657)\end{array}$ & $\%$ & $\begin{array}{c}P \text {-value } \\
\text { (tested vs. } \\
\text { never- } \\
\text { tested) }\end{array}$ \\
\hline \multicolumn{9}{|c|}{ Monthly household income (in euros per household unit) } \\
\hline First quartile $(\leq 1000)$ & 658 & 21.76 & $185 / 306$ & 60.36 & 0.0015 & $148 / 352$ & 42.14 & 0.5919 \\
\hline Second quartile (1001-1499) & 696 & 23.02 & $158 / 316$ & 49.99 & & $167 / 380$ & 43.98 & \\
\hline Third quartile (1500-2199) & 785 & 25.96 & $169 / 362$ & 46.57 & & $168 / 423$ & 39.77 & \\
\hline Fourth quartile $(\geq 2200)$ & 885 & 29.27 & $182 / 439$ & 41.33 & & $174 / 446$ & 38.95 & \\
\hline \multicolumn{9}{|l|}{ Regular general practitioner } \\
\hline Yes & 2558 & 84.62 & $589 / 1163$ & 50.66 & 0.0103 & $579 / 1396$ & 41.46 & 0.4710 \\
\hline No & 465 & 15.38 & $104 / 258$ & 40.21 & & $77 / 202$ & 38.21 & \\
\hline \multicolumn{9}{|l|}{ Had foregone health care } \\
\hline Yes & 510 & 16.87 & $80 / 189$ & 42.08 & 0.0903 & $109 / 321$ & 33.90 & 0.0038 \\
\hline No & 2513 & 83.13 & $613 / 1233$ & 49.72 & & $547 / 1278$ & 42.80 & \\
\hline \multicolumn{9}{|l|}{ Self-perception of HIV risk } \\
\hline High & 495 & 16.37 & $98 / 269$ & 14.21 & 0.0006 & $86 / 226$ & 13.05 & 0.2852 \\
\hline Low & 2528 & 83.63 & $594 / 1154$ & 85.79 & & $571 / 1374$ & 86.95 & \\
\hline \multicolumn{9}{|l|}{ Social support } \\
\hline not supported & 166 & 5.50 & $39 / 79$ & 49.37 & 0.9617 & $43 / 87$ & 49.43 & 0.1165 \\
\hline Supported & 2857 & 94.50 & $654 / 1344$ & 48.66 & & $614 / 1512$ & 40.61 & \\
\hline \multicolumn{9}{|l|}{ Living alone } \\
\hline Yes & 557 & 18.43 & $103 / 262$ & 39.31 & 0.0007 & $159 / 295$ & 53.90 & $<0.0001$ \\
\hline No & 2466 & 81.57 & $590 / 1160$ & 50.86 & & $498 / 1305$ & 38.16 & \\
\hline \multicolumn{9}{|c|}{ Number of steady relationships over lifetime } \\
\hline None & 639 & 21.14 & $216 / 333$ & 64.69 & $<0.0001$ & $199 / 306$ & 64.93 & $<0.0001$ \\
\hline 1 & 1786 & 59.08 & $391 / 787$ & 49.67 & & $387 / 999$ & 38.76 & \\
\hline 2 & 425 & 14.06 & $67 / 210$ & 32.05 & & $56 / 215$ & 26.03 & \\
\hline 3 or more & 173 & 5.72 & $19 / 93$ & 20.33 & & $15 / 80$ & 19.09 & \\
\hline \multicolumn{9}{|l|}{ Religious affiliation } \\
\hline Yes & 2030 & 67.15 & $497 / 894$ & 55.56 & $<0.0001$ & $497 / 1139$ & 43.64 & 0.0093 \\
\hline No affiliation or practice & 993 & 32.85 & $195 / 528$ & 37.02 & & $160 / 461$ & 34.69 & \\
\hline \multicolumn{9}{|l|}{ Neighbourhood variables } \\
\hline \multicolumn{9}{|c|}{ Mean household income (in euros per household unit) } \\
\hline First quartile $(\leq 14,580)$ & 419 & 13.85 & $106 / 188$ & 56.42 & 0.0001 & $108 / 231$ & 46.59 & 0.0855 \\
\hline Second quartile $(14,581-19,074)$ & 757 & 25.03 & $223 / 379$ & 58.98 & & $159 / 378$ & 42.04 & \\
\hline Third quartile $(19,075-25,859)$ & 864 & 28.60 & $177 / 410$ & 43.23 & & $156 / 454$ & 34.29 & \\
\hline Fourth quartile $(\geq 25,860)$ & 983 & 32.52 & $184 / 444$ & 41.49 & & $235 / 538$ & 43.71 & \\
\hline
\end{tabular}


Table 2. Factors associated with never having been tested for HIV among women as determined by multilevel linear regression taken into account neighbourhood variable (model 2$)$ or not (model 1$)$.

$\begin{array}{cc}\text { Model } 1 & \text { Model } 2 \\ \text { aOR }[95 \% \mathrm{CI}] & \text { aOR }[95 \% \mathrm{CI}]\end{array}$

\section{Individual variables}

Age

Religious affiliation

\section{Education level}

\section{Children}

Socio occupational categories

$$
\begin{array}{r}
\text { Lower white-collar } \\
\text { Tradespeople, salespeople } \\
\text { Upper white-collar } \\
\text { Unemployed } \\
\text { Blue collar }
\end{array}
$$$$
\text { No children under } 15 \text { years }
$$$$
\text { Intermediate occupations }
$$

Number of steady relationships over lifetime
$1.27[0.87-1.86]$

Ref.

2.09 [1.50-2.91]

5.09 [3.49-7.42]

Ref.

1.29 [1.00-1.66]

Ref.

2.51 [1.64-3.84]

1.70 [1.21-2.39]

1.24 [0.90-1.71]

Ref.

2.82 [2.06-3.85]

Ref.

0.98 [0.46-2.08]

0.96 [0.66-1.40]

1.85 [1.24-2.76]

0.80 [0.48-1.33]

0.85 [0.61-1.17]

Ref.

1.49 [0.79-2.80]

2.55 [1.44-4.50]

4.32 [2.37-7.90]
1.29 [0.88-1.89]

Ref.

2.09 [1.50-2.92]

5.00 [3.43-7.32]

Ref.

1.27 [0.99-1.64]

Ref.

2.49 [1.69-3.66]

1.72 [1.25-2.36]

1.27 [0.95-1.71]

Ref.

2.89 [2.12-3.95]

Ref.

1.02 [0.48-2.17]

0.98 [0.67-1.43]

1.85 [1.24-2.77]

0.79 [0.48-1.32]

0.85 [0.62-1.18]

Ref.

1.52 [0.81-2.86]

2.52 [1.43-4.46]

$4.22[2.30-7.71]$

\section{Neighbourhood variables}

Mean household income (in euros per household unit)

First quartile $(\leq 14,580)$

Ref.

Second quartile $(14,581-19,074)$

$0.88[0.63-1.24]$

Third quartile $(19,075-25,859)$

$0.63[0.43-0.90]$

Fourth quartile $(\geq 25,860)$

$0.98[0.68-1.42]$

\begin{tabular}{lccc}
\hline Level 2 variance & $0.101(0.045)$ & $0.058(0.045)$ & $0.030(0.038)$ \\
$P$-value & 0.0299 & 0.1701 & 0.2902 \\
Median odds ratio & 1.36 & 1.26 & 1.18 \\
\hline
\end{tabular}

* including 24 pregnant women. 
Table 3. Factors associated with never having been tested for HIV among men as determined by multilevel linear regression taken into account neighbourhood variable (model 2) or not (model 1).

\begin{tabular}{|c|c|c|}
\hline & $\begin{array}{c}\text { Model } 1 \\
\text { aOR 95\%CI }\end{array}$ & $\begin{array}{c}\text { Model } 2 \\
\text { aOR 95\%CI }\end{array}$ \\
\hline \multicolumn{3}{|l|}{ Individual variables } \\
\hline $18-29$ years & $2.52[1.70-3.74]$ & $2.56[1.73-3.80]$ \\
\hline $30-44$ years & Ref. & Ref. \\
\hline Religious affiliation & Ref. & Ref. \\
\hline Yes & $1.36[1.03-1.79]$ & $1.38[1.05-1.83]$ \\
\hline Education level & Ref. & Ref. \\
\hline \multirow[t]{2}{*}{ Self-perception of HIV risk } & Ref. & Ref. \\
\hline & $1.69[1.22-2.35]$ & $1.71[1.23-2.38]$ \\
\hline \multirow[t]{3}{*}{ Migration origin } & Ref. & Ref. \\
\hline & $1.64[1.15-2.35]$ & $1.69[1.18-2.43]$ \\
\hline & $1.62[1.11-2.38]$ & $1.71[1.16-2.52]$ \\
\hline \multicolumn{3}{|l|}{ Number of steady relationships over lifetime } \\
\hline 3 or more & Ref. & Ref. \\
\hline First quartile $(\leq 14,580)$ & & Ref. \\
\hline Second quartile $(14,581-19,074)$ & & $1.31[0.91-1.87]$ \\
\hline Third quartile $(19,075-25,859)$ & & $0.81[0.55-1.20]$ \\
\hline Fourth quartile $(\geq 25,860)$ & & $0.82[0.54-1.23]$ \\
\hline Level 2 variance & $0.000(0.000)$ & $0.000(0.000)$ \\
\hline$P$-value & 0.3989 & 0.3989 \\
\hline Median odds ratio & 1.00 & 1.00 \\
\hline
\end{tabular}

